\title{
CÁC YẾU TỐ TIÊN ĐOÁN KHẢ NĂNG DI CĂN HẠCH RỐN PHỔI VÀ TRUNG THẤT TRONG UNG THU' PHỔI KHÔNG TẾ BÀO NHỎ
}

\author{
Trần Minh Bảo Luân*, Vũ Trí Thanh*
}

\section{TÓM TÁT}

Từ 01/01/2012 đến 31/12/2016 có 109 trường hợp ung thư phổi nguyên phát không tế bào nhỏ được điều trị bằng phẫu thuật nội soi lồng ngực cắt thùy phổi kèm nạo hạch, tuổi trung bình $59,18 \pm 10,08(31-80)$, trong đó 59 nam $(54,1 \%), 50$ nữ $(45,9 \%)$. Kích thước khối u phổi trung bình $3,23 \pm 0,91(1,2-5 \mathrm{~cm})$. Tổng cộng có 419 vị trí hạch được khảo sát, phẫu thuật cho thấy 309 vị trí có hạch, 110 vị trí không có hạch. Vị trí các nhóm hạch và khả năng di căn $(p=0,112)$, số lượng hạch lấy ra tại từng vị trí hạch và khả năng di căn ( $\mathrm{p}<0,001)$, kích thước hạch và khả năng di căn $(p<0,001)$. Vị trí khối u phổi và di căn các nhóm hạch $(\mathrm{p}>0,05)$, kích thước khối u phổi và khả năng di căn các chặng hạch $(\mathrm{p}<0,05)$, khả năng di căn các chặng hạch và loại mô bệnh học $(\mathrm{p}>0,05)$, độ biệt hóa $(\mathrm{p}<0,05)$. Các yếu tố liên quan đến khả năng di căn hạch gồm: số lượng hạch được tìm thấy tại một vị trí của hạch, kích thước khối $u$, mô bệnh học và độ biệt hóa của khối u phổi. Tuy nhiên, chỉ có vị trí của khối u phổi là không liên quan đến khả năng di căn các chặng hạch trong ung thư phổi không tế bào nhỏ.

Từ khóa: phẫu thuật nội soi lồng ngực, di căn hạch, ung thu phổi.

\section{SUMMARY \\ THE PREDICTORS OF HILAR AND MEDIASTINAL LYMPHO NODE METASTASIS \\ IN NON-SMALL CELL LUNG CANCER}

From 01/01/2012 to 31/12/2016 there were 109 cases of primary non-small cell lung cancer treated by VATS lobectomy and lymphadenectomy with an average age of $59.18 \pm$ 10.08 (31 - 80), of which 59 males $(54.1 \%), 50$ females $(45.9 \%)$. The average lung tumor size was $3.23 \pm 0.91(1.2-5 \mathrm{~cm})$. A total of 419 nodal stations were examined, and surgery showed that 309 positive lympho node stations, 110 negative lympho node stations. The location of lympho node and the potential of metastasis $(p=0.112)$, the number of lymph nodes removed at each lympho node station and the probability of metastasis ( $p$ $<0.001$ ), lympho node size and the potential of metastasis ( $p<0.001)$. The location of the lung tumors and metastasis of the lymph nodes ( $p>$ 0.05 ), lung tumor size and lymph node metastasis (p <0.05), metastasis of lymph nodes and histopathology $(p>0.05)$, tumor differentiation ( $p$ $<0.05$ ). The factors related to lymph node metastasis include: number of lymph nodes at each station, tumor size, histopathology and tumor differentiation. However, only the location of tumor is not related to the ability to lymph node metastasis in non-small cell lung cancer.

Keywords: Video-Assited Thoracoscopic Surgery (VATS), Lympho node metastasis, Lung cancer.

\section{I. ĐặT VẤN ĐỀ}

Hiện nay ung thư phổi là là loại ung thư thường gặp nhất và có tỷ lệ tử vong cao nhất cho cả nam lẫn nữ. Tần suất ung thư phổi đang có khuynh hướng giảm nhẹ ở các nước phát triển nhưng lại gia tăng đáng kể ở các nước đang phát triển. Tại Việt Nam, theo báo cáo của Ủy ban phòng chống ung thư quốc gia, tỷ lệ ung thư phổi ở nam là $30,7 / 100.000$ dân và ở nữ là 6,7/100.000 dân. Tỷ lệ này không đổi trong vòng nhiều năm. Theo số liệu của Mỹ (2008) có 169.400 trường hợp mới mắc được chẩn đoán và

\footnotetext{
* Bộ môn phẫu thuật Lồng Ngực-Tim Mạch, Đại học Y Dược TPHCM. Người chịu trách nhiệm khoa hoc: Ths.Bs.Trần Minh Bảo Luân Ngày nhận bài: 01/05/2018 - Ngày Cho Phép Đăng: 20/05/2018 Phản Biện Khoa học: PGS.TS. Đặng Ngọc Hùng
} GS.TS. Lê Ngoc Thành 
154. 000 trường hợp tử vong. Ung thư phổi chiếm tỷ lệ $13 \%$ trong tất cả các loại ung thư, nhưng chiếm đến $28 \%$ tử vong. Đa số các trường hợp ung thư phổi được phát hiện ở giai đoạn muộn không còn khả năng điều trị triệt để, chỉ khoảng $10-20 \%$ các trường hợp ung thư phổi được phát hiện ở giai đoạn còn có khả năng phẫu thuật triệt để. Thời gian sống còn sau phẫu thuật cũng thay đổi rất nhiều, trong đó giai đoạn ung thư phổi hay có di căn hạch là một trong những yếu tố tiên lượng thời gian sống còn. Vì vậy, xác định khả năng di căn hạch rốn phổi và trung thất là một trong những yếu tố quan trọng trong chọn lựa phương án vá xây dựng phác đồ điều trị cho bệnh nhân ung thư phổi.

Mục tiêu nghiên cứu: xác định các yếu tố liên quan đến di căn hạch rốn phổi và trung thất trên bệnh nhân ung thư phổi nguyên phát không tế bào nhỏ được điều trị bằng PT NSLN cắt thùy phổi và nạo hạch.

\section{KẾT QUẢ NGHIÊN CÚU}

\section{1. Đặc điểm nhóm nghiên cứu}

\subsubsection{Tuổi và giới}

Trung bình 59,18 \pm 10,08 (31 - 80); trong đó 59 Nam (54,1\%), 50 Nữ $(45,9 \%)$

\subsection{2. Đặc điểm cận lâm sàng}

Vị trí u phổi

\section{II. ĐỐI TƯợNG VÀ PHƯƠNG PHÁP NGHIÊN CÚU}

Thiết kế nghiên cứu: tiền cứu mô tả dọc, không nhóm chứng.

Đối tượng nghiên cứu: tất cả bệnh nhân ung thư phổi nguyên phát không tế bào nhỏ được điều trị bằng phẫu thuật nội soi lồng ngực cắt thùy phổi kèm nạo hạch tại $\mathrm{BV}$ Đại học $\mathrm{Y}$ Dược TPHCM và $\mathrm{BV}$ Phạm Ngọc Thạch từ 01/01/2012 đến 31/12/2016.

Chỉ định áp dụng cắt thùy phổi qua nội soi lồng ngực:

Ung thư phổi giai đoạn I, IIA, IIIA (T2a,N2) (Định giai đoạn ung thư phổi: phân loại TMN $7^{\text {th }}$ Edition theo UICC hay AJCC 2009); kích thước $\mathrm{u}$ nhỏ hơn $5 \mathrm{~m}$ nằm ở ngoại biên, không xâm lấn mạch máu, thành ngực, rãnh liên thùy, cơ hoành và màng ngoài tim; bệnh nhân không xạ trị vùng ngực trước đó.

\begin{tabular}{lcc}
\multicolumn{3}{c}{ Bảng 1: Vị trí khối u phổi } \\
\hline Vị trí u phổi & Số bệnh nhân $(\mathrm{N}=109)$ & Tỷ lệ (\%) \\
\hline Phổi phải & 22 & 20,2 \\
Thùy trên & 14 & 12,8 \\
Thùy giữa & 30 & 27,5 \\
Thùy dưới & $\mathbf{6 6}$ & $\mathbf{6 0 , 6}$ \\
Tổng & & \\
Phổi trái & 25 & 22,9 \\
Thùy trên & 18 & 16,5 \\
Thùy dưới & $\mathbf{4 3}$ & $\mathbf{3 9 , 4}$ \\
Tổng &
\end{tabular}

Nhận xét: tỷ lệ u phổi bên phải cao hơn bên trái và chủ yếu thùy trên hai bên. 


\subsection{3. Đặc điểm của khối u phổi trên chụp CLVT có cản quang}

Bảng 2: Đặc điểm của khối u phổi trên chụp CLVT có cản quang

\begin{tabular}{lcc}
\hline Đặc điểm của u phổi & $\begin{array}{c}\text { Số bệnh nhân } \\
(\mathbf{N}=\mathbf{1 0 9})\end{array}$ & Tỷ lệ (\%) \\
\hline Kích thước & Trung bình $3,23 \pm 0,91(1,2-5 \mathrm{~cm})$ & \\
$\leq 2 \mathrm{~cm}$ & 7 & 6,4 \\
$>2-3 \mathrm{~cm}$ & 24 & 22 \\
$>3-5 \mathrm{~cm}$ & 78 & 71,6 \\
\hline
\end{tabular}

Nhận xét: đa số khối u phổi có kích thước $\geq 3 \mathrm{~cm}$, tỷ lệ nhỏ kích thước $\leq 2 \mathrm{~cm}$.

Đặc điểm hạch rốn phổi và trung thất trên CLVT

Trong 109 bệnh nhân, có 419 vị trí hạch được khảo sát CLVT cho thấy 225 (53,7\%) vị trí phát hiện có hạch và 194 vị trí không phát hiện hạch trên CLVT.

Vị trí hạch trên CLVT có cản quang

Bảng 3: Vị trí các nhóm hạch trên hình ảnh CLVT lồng ngực cản quang

\begin{tabular}{lcccc}
\hline \multirow{2}{*}{ Vị trí nhóm hạch } & \multicolumn{2}{c}{ U phổi phải (n=65) } & \multicolumn{2}{c}{ U phổi trái (n=44) } \\
\cline { 2 - 5 } & Số bệnh nhân & Tỷ lệ \% & Số bệnh nhân & Tỷ lệ \% \\
\hline Nhóm 2,4* & 30 & 46.2 & 5 & 11.4 \\
Nhóm 5,6 & - & - & 23 & 52.3 \\
Nhóm 7 & 50 & 76.9 & 19 & 43.2 \\
Nhóm 8,9 & 9 & 13.8 & 5 & 11.4 \\
Nhóm 10 & 47 & 72.3 & 37 & 84.1 \\
\hline
\end{tabular}

*: bên trái chỉ có nhóm 4

Nhận xét: hạch được phát hiện trên CLVT nhiều nhất là nhóm 10 , kế đến là nhóm 7 và ít nhât là nhóm 4 bên trái.

3.2. Khả năng di căn các nhóm hạch

3.2.1. Liên quan vị trí các nhóm hạch tìm thấy trong mổ và khả năng di căn

Bảng 4: Khả năng di căn các nhóm hạch theo vị trí

\begin{tabular}{lccc}
\hline \multirow{2}{*}{ Vị trí hạch } & \multicolumn{2}{c}{ Di căn hạch } & \multirow{2}{*}{ Giá trị p } \\
\cline { 2 - 3 } & & Có & \\
\hline Bên phải & $31(79,5)$ & $8(20,5)$ & \\
Nhóm 2, 4 & - & - & \\
Nhóm 5,6 & $42(73,7)$ & $15(26,3)$ & \\
Nhóm 7 & $17(73,9)$ & $6(26,1)$ & \\
Nhóm 8,9 & $42(65,6)$ & $22(34,4)$ & \\
Nhóm 10 & & & \\
Bên trái & $9(90,0)$ & $1(10,0)$ & \\
Nhóm 4 & $21(67,7)$ & $10(32,3)$ & \\
Nhóm 5,6 & $24(85,7)$ & $4(14,3)$ & \\
Nhóm 7 & $11(84,6)$ & $19(43,4)$ & \\
Nhóm 8,9 & $25(56,8)$ & $87(28,2)$ & \\
Nhóm 10 & $22(71,8)$ & & \\
Tổng cộng & & \\
\hline
\end{tabular}

\section{*Phép kiểm Chi bình phuoong}

Nhận xét: Vị trí các nhóm hạch không liên quan với khả năng di căn hạch. 


\subsubsection{Liên quan số lự̛ng hạch lấy ra tại tùng vị trí hạch và khả năng di căn}

Bảng 5: Khả năng di căn hạch theo số lượng hạch được lấy ra tại từng vị trí

\begin{tabular}{lccc}
\hline \multirow{2}{*}{ Số lượng hạch } & \multicolumn{2}{c}{ Di căn hạch } & Giá trị p \\
\cline { 2 - 3 } & Không & Có & \\
\hline 1 hạch & $140(80,5)$ & $34(19,5)$ & \\
3 hạch & $75(62,0)$ & $46(38,0)$ & $<0,001 *$ \\
4 hạch & $7(58,3)$ & $5(41,7)$ & \\
\hline
\end{tabular}

*Phép kiểm chính xác Fisher

Nhận xét: càng nhiều hạch được lấy ra tại 1 vị trí của nhóm hạch thì khả năng di căn hạch càng cao $(\mathrm{P}<0,001)$.

\subsubsection{Liên quan kích thước hạch và khả năng di căn:}

Bảng 6: Khả năng hạch di căn theo kích thước hạch

\begin{tabular}{lccc}
\hline \multirow{2}{*}{ Kích thước hạch } & \multicolumn{2}{c}{ Di căn hạch } & \multirow{2}{*}{ Giá trị p } \\
\cline { 2 - 3 } & Không & Có & \\
\hline$<1 \mathrm{~cm}$ & $210(86,1)$ & $34(13,9)$ & $<\mathbf{0 , 0 0 1 *}$ \\
$\geq 1 \mathrm{~cm}$ & $12(18,5)$ & $53(81,5)$ & \\
\hline
\end{tabular}

*Phép kiểm Chi bình phirong

Nhận xét: kích thước hạch càng lớn thì khả năng di căn hạch càng cao $(\mathrm{P}<0,001)$.

\subsubsection{Liên quan vị trí khối u phổi và di căn hạch các nhóm hạch liên quan}

Bảng 7: Vị trí khối u phổi và khả năng di căn của các nhóm hạch liên quan

\begin{tabular}{lccc}
\hline \multicolumn{1}{c}{ Vị trí u phổi } & \multicolumn{2}{c}{ GPB hạch } & Giá trị P \\
\cline { 2 - 3 } & Không di căn & Có di căn & \\
Thùy trên phải & $12(31,6)$ & $4(22,2)$ & \\
Hạch 2R, 4R & $13(34,2)$ & $5(27,8)$ & P $=0.520^{\mathrm{b}}$ \\
Hạch 7R & $13(34,2)$ & $9(50,0)$ & \\
Hạch 10R & & & \\
Thùy giữa & $6(28,6)$ & $2(16,7)$ & \\
Hạch 2R, 4R & $6(28,6)$ & $5(41,7)$ & \\
Hạch 7R & $9(42,9)$ & $5(41,7)$ & \\
Hạch 10R & & $2(9,5)$ & \\
Thùy dưới phải & $13(17,8)$ & $5(23,8)$ & \\
Hạch 2R, 4R & $23(31,5)$ & $6(28,6)$ & \\
Hạch 7R & $17(23,3)$ & $8(31,8)$ & \\
Hạch 8R, 9R & $20(27,4)$ & & \\
Hạch 10R & & &
\end{tabular}




\section{Thùy trên trái}

Hạch 4L

$7(14,3)$

$12(24,5)$

Hạch 5L, 6L

Hạch 7L

$13(26,5)$

$17(34,7)$

Hạch 10L

\section{Thùy dưới trái}

Hạch 4L

Hạch 5L, 6L

Hạch 7L

Hạch 8L, 9L

Hạch 10L
$2(4,9)$

$9(22,0)$

$11(26,8)$

$11(26,8)$

$8(19,5)$

$222(71,8)$
$1(5,6)$

$8(44,4)$

$1(5,6)$

$8(44,4)$

$0(0,0)$

$2(11,1)$

$3(16,7)$

$\mathrm{P}=0.035^{\mathrm{b}}$

$2(11,1)$

$11(61,1)$

$87(28,2)$

$\mathrm{P}=0.127^{\mathrm{b}}$
Tồng cộng

Nhận xét: liên qua $n$ không có ý nghĩa thống kê giữa vị trí khối u phổi và di căn các nhóm hạch liên quan, trừ khối u ở thủy dưới phổi trái di căn hạch nhóm 10 nhiều hơn các nhóm hạch khác.

3.2.5. Liên quan khả năng di căn các chặng hạch và kích thước khối u:

Bảng 8: di căn các chặng hạch N1 và N2 theo kích thước khối u phổi

\begin{tabular}{|c|c|c|c|c|}
\hline & & \multicolumn{2}{|c|}{ GPB chặng hạch N1 } & \multirow{2}{*}{ Giá trị $P$} \\
\hline & & Không di căn & Có di căn & \\
\hline \multirow{2}{*}{ Kích thước u phổi } & $\leq 3 \mathrm{~cm}$ & 23 & 4 & \multirow{3}{*}{$\mathbf{P}=\mathbf{0 . 0 0 3}^{\mathrm{a}}$} \\
\hline & $>3 \mathrm{~cm}$ & 43 & 39 & \\
\hline \multicolumn{2}{|c|}{ Tông số $=109$} & 66 & 43 & \\
\hline & & \multicolumn{2}{|c|}{ GPB chặng hạch N2 } & \multirow{5}{*}{$P=0.044^{b}$} \\
\hline & & Không di căn & Có di căn & \\
\hline \multirow{2}{*}{ Kích thước u phổi } & $\leq 3 \mathrm{~cm}$ & 23 & 4 & \\
\hline & $>3 \mathrm{~cm}$ & 53 & 29 & \\
\hline \multicolumn{2}{|c|}{ Tổng số $=109$} & 76 & 33 & \\
\hline & & \multicolumn{2}{|c|}{ GPB chặng hạch N1 hoặc N2 } & \multirow{5}{*}{$\mathbf{P}=\mathbf{0 . 0 0 1} 1^{b}$} \\
\hline & & Không di căn & Có di căn & \\
\hline \multirow{2}{*}{ Kích thước u phổi } & $\leq 3 \mathrm{~cm}$ & $22(81,5)$ & $5(18,5)$ & \\
\hline & $>3 \mathrm{~cm}$ & $38(46,3)$ & $44(53,7)$ & \\
\hline \multicolumn{2}{|c|}{ Tổng số $=109$} & 60 & 49 & \\
\hline
\end{tabular}

Nhận xét: khối u phổi có kích thước càng lớn thì khả năng di căn các chặng hạch N1 và N2 càng cao $(\mathrm{P}<0,05)$. 
3.2.6. Liên quan khả năng di căn các chặng hạch và loại mô bệnh học, độ biệt hóa

Bảng 9: di căn các chặng hạch theo loại mô bệnh học và độ biệt hóa của khối u phổi

\begin{tabular}{|c|c|c|c|c|}
\hline & \multicolumn{2}{|c|}{ GPB chặng hạch N1 } & \multirow{2}{*}{$\mathrm{P}$ value } \\
\hline & & Không di căn & Có di căn & \\
\hline \multirow{2}{*}{ Giải phẫu bệnh } & Carcinoma tuyến & 56 & 39 & \multirow{2}{*}{$P=0.559^{a}$} \\
\hline & Các loại khác & 10 & 4 & \\
\hline \multirow{3}{*}{ Độ biệt hóa } & $\mathrm{Cao}$ & 30 & 6 & \multirow{3}{*}{$\mathrm{P}=0.002^{\mathrm{b}}$} \\
\hline & Trung bình & 16 & 13 & \\
\hline & Kém & 20 & 24 & \\
\hline & & \multicolumn{2}{|c|}{ GPB chặng hạch N2 } & \\
\hline & & Không di căn & Có di căn & \\
\hline \multirow{2}{*}{ Giải phẫu bệnh } & Carcinoma tuyến & 65 & 30 & \multirow{2}{*}{$P=0.545^{a}$} \\
\hline & Các loại khác & 11 & 3 & \\
\hline \multirow{3}{*}{ Độ biệt hóa } & $\mathrm{Cao}$ & 31 & 5 & \multirow{3}{*}{$P=0.009^{b}$} \\
\hline & Trung bình & 21 & 8 & \\
\hline & Kém & 24 & 20 & \\
\hline & & \multicolumn{2}{|c|}{ GPB chặng hạch N1 hoặc N2 } & \\
\hline & & Không di căn & Có di căn & \\
\hline \multirow{2}{*}{ Giải phẫu bệnh } & Carcinoma tuyến & $50(52,6)$ & $45(47,4)$ & \multirow{2}{*}{$\mathrm{P}=0.187^{\circ}$} \\
\hline & Các loại khác & $10(71,4)$ & $4(28,6)$ & \\
\hline \multirow{3}{*}{ Độ biệt hóa } & $\mathrm{Cao}$ & $28(77,8)$ & $8(22,2)$ & \multirow{3}{*}{$\mathrm{P}=0.003^{\mathrm{b}}$} \\
\hline & Trung bình & $14(48,3)$ & $15(51,7)$ & \\
\hline & Kém & $18(40,9)$ & $26(59,1)$ & \\
\hline
\end{tabular}

Nhận xét: độ biệt hóa của khối u phổi cảng kém thì khả năng di căn các chặng hạch N1 và N2 càng cao $(\mathrm{P}<0,05)$. 


\section{BÀN LUẬN}

\subsection{Các yếu tố liên quan di căn hạch \\ Số lượng hạch, kích thước hạch và khả năng di căn}

Nghiên cứu của chúng tôi cho thấy số lượng hạch tìm thấy trong mổ tại một vị trí hạch tỷ lệ thuận với khả năng di căn trên mô bệnh học: $19,5 \%$ di căn cho 1 hạch, $38 \%$ và $41,7 \%$ đối với 2 và 3 hạch, $100 \%$ di căn khi có 4 hạch tại một vị trí. Ngoài ra, kích thước hạch đo được trong mổ cũng có liên hệ mất thiết với khả năng di căn, hạch trong mổ với kích thước $>1 \mathrm{~cm}$ có khả năng di căn cao $(\mathrm{p}<0,001)$.

Hiện tại, chúng tôi chưa tìm thấy nghiên cứu nào báo cáo về số lượng hạch tại một vị trí hạch được phẫu thuật lấy ra càng nhiều thì khả năng di căn của nhóm hạch tại vị trí đó càng cao như nghiên cứu của chúng tôi. Tuy nhiên, có một số nghiên cứu đề cập đến số lượng hạch và di căn như sau:

Nghiên cứu của tác giả Nwogu, cho thấy đối với những bệnh nhân không có di căn hạch, tổng số lượng hạch được phẫu thuật lấy ra có giá trị tiên lượng tốt hơn so với vị trí giải phẫu của hạch được tìm thấy. Đối với những trường hợp có di căn hạch, tác giả cũng cho thấy tỷ lệ hạch bị di căn/ tổng số hạch lấy ra (tỷ suất di căn hạch) là yếu tố tiên lượng có giá trị hơn là vị trí giải phẫu của hạch. Bệnh nhân có tỷ suất di căn hạch (dưới $25 \%$ ) hoặc trung bình (25 - 49\%) có tiên lượng tốt hơn những người có tỷ suất di căn hạch cao (hơn 50\%).

Tác giả Kaiser L.R. và cs (2004) thực hiện nghiên cứu với 753 trường hợp, tác giả phân loại di căn vào 1 nhóm hạch, 2 nhóm hạch và hơn 3 nhóm hạch, không phân biệt là hạch chặng N1 hay $\mathrm{N} 2$ thì thời gian sống thêm 5 năm tỷ lệ nghịch với số nhóm hạch bị di căn. Đặc biệt nếu di căn từ 3 nhóm hạch trở lên, không có $\mathrm{BN}$ nào sống quá 5 năm.
Theo tác giả Takayuki (2006), trong số các bệnh nhân có di căn chặng N2, nhóm có 1-3 hạch di căn có tỷ lệ sống còn tốt hơn so với nhóm có 46 và nhóm có 7 hạch di căn. Tác giả kết luận, số lượng hạch bạch huyết di căn là một yếu tố tiên lượng độc lập trong ung thư phổi và có thể thêm dữ liệu này vào bảng phân loại TNM hiện tại.

Tác giả Lee và cs, trong nghiên cứu của mình cũng cố gắng để xác định xem số lượng hạch di căn, tổng số hạch được phẫu thuật lấy ra và tỷ suất di căn của hạch là yếu tố tiên lượng sự sống còn tốt hơn vị trí giải phẫu của hạch (chặng N1, N2). Tuy nhiên, theo tác giả Valerie (2015), cho đến nay các nghiên cứu phân tích đều thất bại trong việc chỉ ra rằng số lượng hạch thay thế vị trí giải phẫu của hạch (chặn N1, N2) như là một yếu tố tiên lượng. Và khẳng định vị trí các chặng hạch $(\mathrm{N} 1, \mathrm{~N} 2)$ sẽ vẫn là phương pháp đánh giá phân độ $\mathrm{N}$ trong phiên bản thứ 8 sắp tới của hệ thống phân loại ung thư quốc tế.

\subsection{Vị trí u và di căn các nhóm hạch liên quan:}

Theo Koutolas và cs (2004) có 557 trường hợp ung thư phổi được phẫu thuật nhận thấy: khối u thùy trên phổi phải hay di căn hạch nhóm 4 và 7 , khối u thùy dưới phải hay di căn hạch nhóm 7 , khối u thùy trên trái hay di căn hạch nhóm 5 , khối u thùy dưới phổi trái hay di căn hạch nhóm 7 và 8,9 .

Theo Cerfolio và cs (2006), phân tích 954 trường hợp ung thư phổi thấy: $27 \%$ u thùy trên phổi phải di căn vào hạch nhóm $4 \mathrm{R} ; 15 \%$ u thùy giữa và $30 \%$ u thùy dưới phổi phải di căn hạch nhóm $4 \mathrm{R}$ và $7 ; 20 \%$ u thùy trên phổi trái di căn hạch nhóm $6 ; 22 \%$ u thùy dưới phổi trái di căn hạch nhóm 7.

Tác giả Harvey I.P. và cs (2010) đã phân tích số liệu từ 390 trường hợp ung thư phồi cho thấy: 
U thùy trên phổi phải tỷ lệ di căn hạch nhóm 2 là $21 \%$; di căn hạch nhóm 4 rất cao là 64\%; di căn hạch nhóm 7 là 22\%; di căn hạch nhóm 10 là $31 \%$. U thùy giữa di căn hạch nhóm 4 cao $67 \%$; di căn hạch nhóm 7 là $50 \%$; di căn hạch nhóm 10 là $43 \%$. U thùy dưới phổi phải di căn hạch nhóm 3, 4 là 25\%; nhóm 8-9 rất thấp chỉ $3 \%$; đăc biệt di căn hạch nhóm 7 rất cao là $86 \%$; di căn hạch nhóm 10, 12 là 48\%.

U thùy trên phổi trái di căn hạch nhóm 2 rất thấp chỉ $2 \%$; di căn hạch nhóm 4 là $16 \%$; di căn hạch nhóm 7 là 21\%; đăc biệt di căn hạch nhóm 5-6 rất cao 90\%; di căn hạch nhóm 10 là 36\%. U thùy dưới phổi trái di căn hạch nhóm 3,4 là $15 \%$; di căn hạch nhóm 5-6 là 39\%; di căn hạch nhóm 8-9 rất thấp chỉ $2 \%$; di căn hạch nhóm 7 cao là $55 \%$; di căn hạch nhóm 10 là 52\%.

Kết quả nghiên cứu của chúng tôi (Bảng 7) cũng cho thấy tỷ lệ di căn vào các nhóm hạch của khối u ở các thùy phổi tương tự như các tác giả trên. Chúng tôi cũng không tìm thấy có sự liên quan có ý nghĩa thống kê về sự di căn giữa các nhóm hạch cho từng vị trí của thùy phổi có khối u.

\subsection{Kích thước u và di căn các chặng hạch:}

Kết quả của chúng tôi (Bảng 8) cho thấy kích thước khối u liên quan mật thiết với mức độ di căn hạch, khối u với kích thước $\leq 3 \mathrm{~cm}$ thì tỷ lệ di căn hạch chỉ $18,5 \%$, trong khi đó khối u có kích thước $>3-5 \mathrm{~cm}$ thì tỷ lệ di căn hạch là $53,7 \%$. $(\mathrm{P}=0,001)$

Theo Bùi Chí Viết (2011) phẫu thuật 104 $\mathrm{BN}$ cũng có nhận xét tương tự khối $\mathrm{u}$ đk $\leq 30 \mathrm{~mm}$ tỷ lệ di căn hạch là 23,1\%; u đk 31- 50 mm di căn hạch là 40,9\%.

Tác giả Nguyễn Khắc Kiểm (2016) cho thấy khối u kích thước $\leq 30 \mathrm{~mm}$ có tỷ lệ di căn hạch thấp 31,5\%; khối u có kích thước >30 - 50 mm có tỷ lệ di căn hạch vùng cao nhất $43,2 \%$.

Luketich J.D. và cs (1996) ghi nhận khối u kích thước $\leq 10 \mathrm{~mm}$ thì tỷ lệ di căn hạch vùng là
$0 \%$; khối u kích thước từ $11-20 \mathrm{~mm}$ và > $20 \mathrm{~mm}$ di căn hạch vùng tương ứng là $17 \%$ và $38 \%$.

Tác giả Pei Ying Lin và cs (2010) thực hiện hồi cứu trên 932 trường hợp ung thư phổi cho thấy: khi kích thước khối $\mathrm{u}>25 \mathrm{~mm}$ ở loại ung thư tế bào tuyến thì khả năng di căn hạch cao $80 \%$, trong khi nhóm ung thư tế bào gai thì kích thước khối u > 40 mm mới tăng khả năng di căn hạch $(\mathrm{p}=0,001)$.

Asamura $\mathrm{H}$ và cs (2010) cho rằng với những khối $\mathrm{u}$ ở giai đoạn sớm kích thước $\leq 20$ mm không cần thiết phải nạo vét hạch chặng N2 vì không cải thiện được thời gian sống thêm. Tuy nhiên những trường hợp khối $\mathrm{u}$ kích thước từ 21$30 \mathrm{~mm}$ tỷ lệ di căn hạch trung thất N2 là $16 \%$ cần phải nạo vét hạch hệ thống.

Nhìn chung, kết quả nghiên cứu của chúng tôi củng như các tác giả khác đều cho thấy kích thước khối u có liên quan mật thiết với di căn hạch.

\subsection{Mô bệnh học, độ biệt hóa khối u liên quan di căn hạch}

Kết quả Bảng 9 cho thấy ung thư tế bào tuyến có tỷ lệ di căn hạch $47,4 \%$, so với các loại khác thì tỷ lệ di căn hạch chỉ có $28,6 \%$. Những trường hợp biệt hóa cao thì tỷ lệ di căn hạch thấp $22,2 \%$, biệt hóa trung bình và kém có tỷ lệ di căn hạch cao $51,7 \%$ và $51,9 \%$. ( $\mathrm{P}=0,003)$.

Tác giả Bùi Chí Viết (2011) với 104 trường hợp ung thư phổi thấy tỷ lệ di căn hạch theo mô bệnh học: ung thư tề bào tuyến di căn hạch là $41,5 \%$; ung thư tế bào gai di căn hạch là $34,6 \%$; ung thư tế bào lớn $25 \%$; ung thư tế bào các loại khác $40 \%$.

Tác giả Cung Văn Công (2015) nghiên cứu 102 trường hợp ung thư phổi, thây rằng ung thư loại biểu mô tuyến thường di căn hạch nhóm $4 \mathrm{R}$ với 51 trường hợp $(50,0 \%)$, kế đến là hạch nhóm $2 \mathrm{R}$ với 39 trường hợp $(38,2 \%)$.

Tác giả Nguyễn Khắc Kiểm (2016) thấy ung thư tế bào tuyến có tỷ lệ di căn hạch cao nhất $42 \%$; 
ung thư tế bào gai ít thấy di căn hạch $32,9 \%$; hai nhóm còn lại là ung thư tế bào lớn, ung thư tế bào các loại khác có tỷ lệ di căn hạch $35 \%$.

Tác giả Fujimura $S$ và cs (2007) qua 2058 trường hợp nhận thấy ung thư tế bào tuyến có tỷ lệ di căn hạch cao là $43 \%$; ung thư tế bào gai là $30 \%$ và ung thư tế bào lớn có tỷ lệ di căn hạch thấp 19\% nhưng thường di căn xa.

Shimosato Y (2010) nghiên cứu phẫu thuật trên 120 trường hợp ung thư phổi thấy ung thư tế bào tuyến hạch di căn $(\mathrm{N} 1, \mathrm{~N} 2)$ có tỷ lệ là $30,3 \%$; ung thư tế bào gai di căn hạch là $20,7 \%$; ung thư tế bào lớn di căn hạch thấp là 13,4\%.

Tác giả Fei Zhao (2017) nghiên cứu 284 trường hợp ung thư phổi, cho thấy tỷ lệ di căn hạch của ung thư tế bào tuyến $23 \%$ so với $33 \%$ có di căn hạch của ung thư tế bào gai. Tuy nhiên, sự khác biệt này không có ý nghĩa thống kê ( $\mathrm{P}=$ 0,176). Ngoài ra, nghiên cứu của tác giả còn cho thấy độ biệt hóa của khối u càng cao thì tỷ lệ di căn các nhóm hạch thấp và ngược lại $(\mathrm{P}=0,001)$; Khối u có độ biệt hóa cao di căn hạch $6,9 \%$, biệt hóa trung bình và biệt hóa kém di căn hạch 32,4\% và $27,3 \%$.

Như vậy, kết quả nghiên cứu của chúng tôi cũng tương tự như các tác giả khác đều cho thấy tỷ lệ di căn hạch của ung thư tế bào tuyến cao hơn tế bào gai và các loại khác. Ngoài ra, độ biệt hóa của khối u cũng liên quan đến tỷ lệ di căn hạch, khối u biệt hóa cao có tỷ lệ di căn hạch thấp hơn biệt hóa trung bình và kém.

\section{KẾT LUẬN}

Qua nghiên cứu của chúng tôi và phân tích nghiên cứu của các tác giả khác, chúng tôi nhận thấy các yếu tố liên quan đến khả năng di căn hạch rốn phổi và hạch trung thất trong ung thư phổi không tế bào nhỏ bao gồm: số lượng hạch được tìm thấy tại một vị trí của hạch, kích thước hạch và khối $u$, mô bệnh học và độ biệt hóa của khối u phổi. Tuy nhiên, chỉ có vị trí của khối u phổi là không liên quan đến khả năng di căn các chặng hạch trong ung thư phổi không tế bào nhỏ.

\section{TÀI LIỆ THAM KHẢO}

1. Ngô Quý Châu (2011). Ung thư phổi tiên phát. Bệnh hô hấp. Nhà xuất bản giáo dục Việt Nam, pp. 223-268.

2. Cung Văn Công (2015), Nghiên cúu đặc điểm hình ảnh cắt lớp vi tính đa dãy đầu thu ngực trong chẩn đoán ung thu phổi nguyên phát ờ người lớn, Luận án tiến sỹ Y học, Viện nghiên cứu khoa học y dược học lâm sàng 108, Hà Nội.

3. Nguyễn Khắc Kiểm (2016), Nghiên cưu nạo vét hach theo bản đồ trong phẫu thuật điều trị ung thu phổi không tế bào nhỏ giai đoạn I - II - IIIA, Luận án tiến sỹ Y học, Đại học Y Hà nội, Hà Nội.

4. Bùi Chí Viết (2011), Phẫu trị Ung thu phổi nguyên phát không tế bào nhỏ, Luận án Tiến sỹ Y học, Đại học Y dược thành phố Hồ Chí Minh, Thành phố Hồ Chí Minh.

5. Asamura H., Suzuki K., Kondo H., Tsuchiya R. (2010). Where is the boundary between N1 and N2 stations in lung cancer?. Annals of Thoracic Surgery, 70, pp. 1829-45.

6. Cerfolio, R. J. and Bryant, A. S. (2006), "Distribution and likelihood of lymph node metastasis based on the lobar location of nonsmall-cell lung cancer", Ann Thorac Surg. 81(6), pp. 1969-73.

7. Fei Zhao et al (2017). A prediction model for lymph node metastases using pathologic features in patients intraoperatively diagnosed as stage I nonsmall cell lung cancer. BMC Cancer 17:267. DOI 10.1186/s12885-017-3273-X.

8. Ferlay J, et al. (2010). Estimates of worldwide burden of cancer in 2008: GLOBOCAN 2008. Int J Cancer. 127(12), pp. 2893-917. 
9. Fujimura S., Saito Y., Sagawa M., et al (2007). The assessment for the surgical treatment of lung cancer evaluated from 2058 operated cases. Lung Cancer Surgery, pp. 152-425.

10. Harvey I. Pass, David P.C, David H.J, John D.M (2010). Lung Cancer principles and practicce, 4rd edition, Lippincott William and Wilkins a Wolters Kluwer Company.

11. Kaiser L.R., Shrager J.B. (2004). Text book of surgery, The biological basis of mordern surgical practic. Thoracoscopy Surg, 15th edition, pp. 1806-1814.

12. Kotoulas, C. S., et al. (2004), "Involvement of lymphatic metastatic spread in nonsmall cell lung cancer accordingly to the primary cancer location", Lung Cancer. 44(2), pp. 183-91.

13. Lee S, Lee HY, Lee KS, et al (2015). "Change of the junctions between stations 10 and 4 in the new International Association for the Study of Lung Cancer lymph node map: a validation study from a single tertiary referral hospital experience”. Chest. 147(5): 1299 - 1306.

14. Lin P. Y., Chang Y. C., Chen H. Y., et al (2010). Tumor size matters differently in pulmonary adenocarcinoma and squamous cell carcinoma. Lung Cancer, 67, pp. 296-300.

15.Luketich J.D., Ginsberg R.J. (1996). Limited resection versus lobectomy for stage I non small cell lung cancer. Lung cancer: principles and practive, Lippincott - Paven Publishers, Philadelphia, pp. 561-6.

16. Nwogu C. E. et al. (2012). Number of Lymph Nodes and Metastatic Lymph Node Ratio Are Associated With Survival in Lung Cancer. Ann Thorac Surg 2012;93:1614 -20.

17. Shimosato Y. (2010). Pulmonary Neoplasms. Diagnostic surgical pathology, Lippincott William \& Wilkins, Philadelphia, pp. 1069-15.

18. Takayuki F., et al (2006). "Significance of the Number of Positive Lymph Nodes in Resected Non-small Cell Lung Cancer". J Thorac Oncol;1: 120-125.

19. Valerie W. R. (2015). Lymph nodes in lung cancer. journal.publications.chestnet.org. DOI: 10.1378/chest.14-2767. 